\title{
2
}

\section{Fragments of Communicative Memory: World War II, Tito and the 1992-95 War}

Depending on their age, Mostarians have been exposed to different nationality politics, often in conflict with one another. We should not, however, imagine nationality politics as a top-down process whereby citizens are pictured as empty containers who passively accept these politics wholesale. This view has often directed the analysis of transient regimes, as Keith Brown points out:

Yet in a region of transient regimes, what is emphasised about the inhabitants is their supposed willingness to adopt another national affiliation quickly. In parallel fashion, the new state is presumed to be ready and able to accept them as tabulae rasae and to inscribe national identity on them anew. [...] What one might term 'experienced' history drops out of sight as the rhythm of every aspect of life is taken to be determined by the continuities or disjunctures in 'top-down' history. (Brown 2003: 129)

This book counters such representations by demonstrating that individuals are shaped by the experiences of the different historico-political periods through which they lived. These experiences may show continuities and discontinuities and may agree or conflict with each other, but they have an impact on people's perceptions of their society and their past.

(C) The Editor(s) (if applicable) and The Author(s) 2016

M. Palmberger, How Generations Remember,

DOI 10.1057/978-1-137-45063-0_2 
In discussing the historical periods that can still be encountered in communicative memory (Assmann and Czaplicka 1995), this chapter shows how politically turbulent recent Yugoslav history has been. It provides insights into the historico-political periods Mostarians (depending on their ages, of course) have lived through and, more importantly, it discusses changing memory and identity politics individuals of different generations were exposed to as well as different forms of neighbourliness (komšiluk).

\section{World War II in the Territory of Present-Day Bosnia and Herzegovina}

Fighting within the territory of Yugoslavia during WWII-from the Nazi occupation of Yugoslavia in 1941 to their defeat in 1945-was extremely complex, especially when accounting for the various forces and oscillating alliances:

The history of the Second World War in Yugoslavia is the story of many wars piled one on top of another. First, of course, there was the initial war conducted by Germany and Italy against Yugoslavia itself. [...] There was also the war of the Axis occupiers against Yugoslav resistance. [...] And then there were at least two civil wars. One was a war conducted by Croatian extremists [Ustasha] against the Serb population of Croatia and Bosnia, a war of aggression on one side and sometimes indiscriminate retaliation on the other. And finally there was a war between the two main resistance organizations in which the Serbs from those areas enlisted: the Četniks and the Communist Partisans. (Malcolm 2002: 174)

The three key players-Chetniks (Četnici), Ustashe (Ustaše) and the Partisans (Partizani)_cannot be clearly distinguished along national lines, even if Serbs were predominant among the Chetniks and Croats predominant among the Ustashe. People of other nationalities joined them, though in far smaller numbers.

Germany defeated the Kingdom of Yugoslavia within 11 days, ${ }^{1}$ a campaign that exemplified the concept of blitzkrieg. Even before

\footnotetext{
${ }^{1}$ For a detailed discussion about the interwar period, see Lampe 1996.
} 
Yugoslavia surrendered, the Independent State of Croatia (Nezavisna Država Hrvatska, NDH) — a quasi-puppet state—had been established with the support of Germany and Italy in April $1941 .^{2}$ The centre of the $\mathrm{NDH}$, led by Ante Pavelić, was in Zagreb but the NDH also incorporated the whole of $\mathrm{BiH}$, whereby Mostar came under Italian rule. Most Croats accepted the new regime and many saw it as liberation from Serb hegemony. Ante Pavelić became the declared Fuehrer of NDH and his Ustasha organisation started to 'cleanse' the territory of any non-Croats, mainly Serbs and Jews, since Muslims were perceived as quasi-Croats. The NDH's population included $51 \%$ Croats; among the remaining half $30 \%$ were Serbs and $12 \%$ Muslims. In the territory of $\mathrm{BiH}$, by contrast, the population was predominantly Serb and Muslim. But here, too, the $\mathrm{NDH}$ directed its aggressive activities against the Serb rather than the Muslim population. The Croat claim that the Muslims were of Croat and Catholic or Bougumil origin was countered by the Serb claim that the Muslim population was in fact Serb. These claims were significant because incorporating Bosniaks into the Serb or Croat nation had been practised since the mid-19th century by both Croats and Serbs in order to claim the territory of $\mathrm{BiH}$, a practice that was to continue into the post-WWII period.

NDH terror against Serbs began soon after the German occupation. In June 1941 a mass arrest of Serbs occurred in Mostar; hundreds were shot and their bodies thrown into the Neretva River. 'Anti-semitism was of only secondary concern to Ustaša ideologists. The main aim was to "solve" the problem of the large Serb minority (1.9 million out of a total of 6.3 million) in the territory of the NDH' (Malcolm 2002: 176). The Ustasha set Croats apart from the Slav population by proclaiming themselves as 'pure Aryans' of Gothic or Persian descent. Most Serb men able to fight joined either the Chetnik led by Draža Mihajlović or the Partisan

\footnotetext{
${ }^{2}$ The Ustasha movement was almost unknown to the population before the war and in the beginning found little support among the majority of Croats but received strong support from the local Catholic Church. When the NDH merged into $\mathrm{BiH}$, it attempted 'to eliminate from its territory the communists (of all ethnic backgrounds), Serbs who refused to convert into "Orthodox Croats", the Jews, and the Gypsies (Roma)' (Perica 2002: 24; see also Carmichael 2002). Muslims were not seen as a separate nation but were called 'Muslim Croats' (see Perica 2002: 22). On the church's support for the NDH, see Jäger 2001. Cohen and Riesman (1996) provide insight into the generally unknown collaboration of Serbs in the destruction of the Jews.
} 
movement led by Josip Broz Tito to fight the Ustasha. The Chetnik reaction against the Ustasha was particularly brutal in Herzegovina, where they killed Croat and Muslim villagers whose acquiescence in NDH rule they regarded as collaboration. There were also Serb fascist tendencies towards a 'homogeneous Serbia' including Bosnia and Herzegovina and other parts of Yugoslavia and directed primarily against Jews, but also Croats and Muslims (Velikonja 2003: 165). ${ }^{3}$

Although the majority of Muslims were opposed or at least indifferent to the Pavelić regime, some of the Muslim population supported it, particularly those who had been strongly pro-Croat during the interwar period (Tomasevich 2001: 491). A sizable number of Muslims joined Ustasha militia units and helped perpetrate atrocities against the Serb population. Gradually, however, more and more Muslims openly opposed the Ustasha regime and spoke out against the persecution of innocent Serb clergy and civilians. There were also those who joined the Partisans, thereby revolting against the Ustasha. This was also the case in Mostar (see Tomasevich 2001; Wilson 1979). The communist Partisans fought both against the Chetniks, who aimed for a rebirth of a Serb-dominated Yugoslav monarchy, and against the Ustashe, who were allies of Germany (see Pavkovic 1997; Schmider 2002; Schöpflin 1993).

At the beginning of WWII, the Partisans, who were fighting for a socialist Yugoslavia, fought independently and only later aligned with the Allies. At the first session of the National Antifascist Council of National Liberation of Bosnia and Herzegovina (ZAVNOBiH-Zemaljsko antifašističko vijeće narodnog oslobodjenja Bosne i Hercegovine) on 25 November 1943 in Jajce, the wartime Partisan parliament voted for a new Yugoslavia. It envisioned this new Yugoslavia as a federation of six republics and two provinces. The future $\mathrm{BiH}$ was defined as one of the six republics of the three equal nations: Muslims, Croats and Serbs (Bougarel 1996: 92).

The Konjic Battalion (renamed Mostar Battalion in June 1942) was formed in September 1941. Although Muslims were in the majority, it was a multinational unit and included Croats, Serbs, Montenegrins, Jews and others (see Hoare 2005). When Nenad Vasić took over the role of

\footnotetext{
${ }^{3}$ Out of the around 14,000 Jews living in $\mathrm{BiH}$, about 12,000 were killed during WWII (Malcolm 2002: 176).
} 
command in January 1942, the Mostar Battalion turned to the extreme left and Vasić proceeded to terrorise his own Partisans:

In practice, the 'revolutionary' terror of the Mostar Battalion tended to resemble the terror practised by its 'reactionary' enemies, the Chetniks and Ustashas. Thus, in the words of a contemporary Partisan report, the battalion 'had from the start an unjust attitude towards Croats. During the seizure of Croat villages unjust liquidations were enacted and a whole series of other errors committed. Captured Croats were subject to torture and later executed. All those steps had as a result the exodus of the Croat population from the territory held by the Partisans'. (Hoare 2005: 230)

When Vasić was finally removed as commander at the end of September 1942, the Mostar Battalion was incorporated into the 10th Hercegovinian Brigade. Hoare concludes that '(d)espite of the traumas experienced by the Partisans of the Mostar Battalion, they proved to be the most reliable in northern Hercegovina as those from urban backgrounds were immune to Chetnik agitation' (Hoare 2005: 233). The urban origin of Mostar's Partisans is still visible in their commemorations that take place to this day (see Chap. 4).

During WWII, losses were experienced on all sides, but among Muslims they were particularly high (Tomasevich 2001). Muslims fought-and were killed-on all sides. Altogether around 75,000 Bosnian Muslims died in the war. This represented $8.1 \%$ of their total population and was the highest loss suffered by any people in Yugoslavia except for the Jews and Gypsies (see Malcolm 2002; Schöpflin 1993). It is also important to note that generally more Yugoslavs were killed by other Yugoslavs than by the occupying forces (Allcock 2000: 270), surely a difficult legacy for the second Yugoslavia. Mostar, however, not only saw conflict and atrocities during WWII; it was also an important centre of resistance (Bose 2002).

\section{The Second Yugoslavia and Memory Politics Under Tito}

After the fascist occupiers had been defeated (which, as far as Mostar is concerned, was on 14 February 1945), the second Yugoslavia under Tito was established. The newly established $\mathrm{BiH}$ constituted a republic with 
its Austro-Hungarian borders reinstated. ${ }^{4}$ This was not appreciated by all former war parties, least of all by Croat and Serb extremists, who longed for a Great Croatia and Great Serbia, respectively, incorporating the territory of $\mathrm{BiH}$. They both rested their claims on history and, as noted above, each argued that the Muslim population was originally Croat or Serb (see Banac 1993; Cohen 1995).

The Partisans who assumed power after WWII were best positioned to present themselves as the winners of the war since they claimed to have expelled the foreign occupiers and to also have defeated their internal enemies (Schöpflin 1993: 179). To Tito, however, it seemed too difficult (and too dangerous due to the risk of renewed tensions) to address the period other than by speaking of the Yugoslavs as fighting collectively against the Nazis (see Palmberger 2006).

Josip Broz Tito became the central figure of the second Yugoslavia and established a cult around himself that would persist for some years, even after his death. Tito was portrayed as a 'creator and saviour', a 'peacemaker' and a 'defender of truth' (Perica 2002: 103). Central to the Tito cult was the annual Titova štafeta (Tito's Relay), later called Štafeta mladosti (Youth Relay), which took place annually on 25 May. It was a race through Yugoslavia for Tito's birthday and was taken to be a symbol of brotherhood and unity and of a shared Yugoslav dream. Titova štafeta outlived Tito and continued to take place until 1987. One could even say that it has outlived Tito to the present day, at least in the memories of many people.

Many of my oldest informants narrated the post-WWII period as a time of new beginnings rather than of persisting tensions between the former warring parties. Perhaps these memories are linked to my interlocutors' young age at the time; many were teenagers and remember the economic hardship of that time rather than the national tensions. But after WWII Mostar was not a divided city in the way it is today, and from this perspective the tensions may in retrospect seem negligible. Presumably it was also Tito's strong grip on the politics of memory that prevented persisting tensions from becoming a subject of discussion.

\footnotetext{
${ }^{4}$ Already in 1580 the province of Bosnia was created under Ottoman rule. It included entire present $\mathrm{BiH}$ and some neighbouring parts of Croatia, Dalmatia, Slavonica and Serbia (see Malcolm 2002).
} 
Tito's patriotic education was not based on a melting-pot metaphor but, quite the contrary, stressed the distinctiveness of the different nations (in the meaning of narod) living in the territory of Yugoslavia. However, brotherhood and unity was the concept chosen to prevent more conflict, which would hinder Yugoslavia from prospering (see Perica 2002). This ideology was also promoted by artists, for example, by the popular rock band Bijelo Dugme from Sarajevo who in one of their popular songs sang 'There is a secret link, a secret link for all of us'. Bijelo Dugme, together with a number of other rock bands from that time, still triggers strong sentimental emotions among many of the Last Yugoslavs who associate these bands and their music with their youth and the spirit of Yugoslavia (see Chap. 5).

Tito's self-created myth fell on fertile soil not only in Yugoslavia, but also outside of it. He was often credited with bringing peace and reconciliation to the region. Thus Tito's admirers closed their eyes to his aspirations for power and the war crimes committed under his orders at the end of WWII. Between 1945 and 1946, up to 250,000 people vanished through Tito's detention camps, death marches and mass shootings. One event still remembered today (mainly by Croats) is the tragedy of Bleiburg (Radonic 2010). When the Partisans met the British troops in this Austrian town in April 1945, the British handed over more than 18,000 captured members of various anti-Partisan forces (Slovene home guards, Ustasha soldiers as well as Serb and Muslim Chetniks) who had sought refuge in Allied-controlled Austria. Most of them were massacred when they reached Yugoslavia (Malcolm 2002: 193; see also Pavlowitch 1992). These war crimes were one of the best-kept secrets and what happened in the years of 1945 and 1946 became taboo. The same was true for the internal wars fought during WWII:

As Communist rule entailed ideological control over the representation of the past, those horrifying events that would disrupt interethnic cooperation were not to be mentioned, except in collective categories, all 'victims of fascism' on one side, and all 'foreign occupiers and domestic traitors' on the other side. (Denich 1994: 370)

The Yugoslav people were portrayed as brave communist Partisan fighters who defeated the evil fascists. This image of the heroic Yugoslavs was 
excessively repeated in school books and in movies (e.g., in The Battle of Neretva) (see Jäger 2001). All this was an act of memory politics that attempted to stop any further antagonism between the national groups, and aimed (at least in the initial years of Tito's rule) to create a single identity in a unified state through a single memory. Brotherhood and unity was the ideology upon which the Titoist state claimed to be founded. It was the leitmotif to encourage people to live peacefully together after the atrocities of WWII.

Tito's period of rule can be divided into two parts: a repressive regime and a relatively liberal regime. Depending on their age, my interlocutors experienced Yugoslavia in very different ways. Only the First Yugoslavs lived through the entire period of Tito's Yugoslavia and thus experienced Tito as a strict dictator and as a 'generous state father' who brought economic prosperity and peace to the region. It might be assumed that those who experienced Tito's first period of rule show a more ambivalent attitude towards the former statesman, but this is not necessarily the case. Among the First Yugoslavs are also those who show the greatest, most undivided loyalty to Tito (discussed in Chap. 4).

Within the repressive phase fall the above-mentioned atrocities in Bleiburg in 1945, as well as the detention camps, the most infamous of them being Goli Otok. It was a phase of strong centralism from Belgrade. After breaking with Stalin in 1948, all those who were rightly or wrongly accused of being Stalin supporters faced jail or detention camps. These atrocities committed during Tito's period of rule (together with other atrocities committed during WWII) only became a subject of public discussion after Tito's death. However, the atrocities were primarily discussed from a nationalist vantage point, with the aim of supporting the claim for the victimisation of one's group-Serb, Croat or Bosniak-rather than as a criticism of socialism under Tito in more general terms (see Allcock 2000; Bet-El 2002; Denich 1994; Gilbert 2006; Hayden 1994; Price 2002).

The post-WWII period was also a time of economic reconstruction with rapid industrialisation. This was tackled by financial aid from the United Nations, and the Communist Party of Yugoslavia organised youth brigades who participated in the radne akcije (working projects). Moreover, in 1946 the Yugoslav government turned over agricultural 
land to those who tilled it in order to reward the peasants who were the backbone of support for the Partisan liberation. Not surprisingly this reform was greatly opposed by the former land owners (Donia and Fine 1994: 165-166). ${ }^{5}$

The first period of Yugoslavia ends in the mid-1960s with an economic reform (in 1965) and the fall of the head of the police apparatus, Aleksandar Ranković (in 1966) (Lovrenović 1999: 170). In $\mathrm{BiH}$ this change went hand in hand with a transfer of leading positions from the old Serb elite to the young generation consisting also of Muslims and Croats. Gradually, more and more power was given to the six republics. The idea of selfmanagement, first introduced during the 1950s, was one aspect of this power transfer. 'Self-management was a theoretically inspired response to Marx's complaint that workers in a capitalist society are alienated from the means of production' (Donia and Fine 1994: 171). Self-management was intended to grant more power to workers at the factories and enterprises and to reduce the power of state central planners. The former was realised by gradually establishing workers' councils, but the latter did not follow (Donia and Fine 1994: 171; see also Dyker 1990). The one-party state also remained during the second phase, with Tito as the president-forlife of Yugoslavia. ${ }^{6}$ In the second phase, however, Yugoslavia distinguished itself from Soviet-style communism due to its relative freedom of movement and opinion (see Allcock 2000). Furthermore, Tito's initial attempts to marginalise religion were no longer dominant in the second phase of his rule (see Velikonja 2003; Wilson 1979).

Tito is still remembered fondly by many Mostarians through the generations as shown in this book. Although so-called Tito-nostalgia can be found in all Yugoslav successor states, $\mathrm{BiH}$ had an extraordinarily strong relationship with Tito: 'In no republic was Tito's stature greater than in Bosnia, home of the Partisan movement and of his most disciplined

\footnotetext{
${ }^{5}$ For a long time the Muslims were in possession of the great majority of land, certainly under the Ottoman Empire, but this continued even into the Habsburg Empire era. 'As late as 1910, more than thirty years after the end of the Ottoman presence in Bosnia, 91.1 per cent of the landed proprietors having kmetovi (tenant farmers with feudal obligations) were Muslims, while 95.4 per cent of the kmetovi were Orthodox or Catholic' (Bougarel 1996: 88).

${ }^{6}$ In the early 1970s an amendment to the constitution was made to ensure that Tito would be president for life. Moreover, Tito was so determined not to lose power that he refused to select or support anyone from among those close to him to become his successor.
} 
and Orthodox Party organization' (Donia and Fine 1994: 191). Those who might be called Yugo-nostalgists primarily remember Tito's second period of rule (Palmberger 2008). Their discourses emphasise how distinct Yugoslavia was from all the other socialist countries. It is true that Yugoslavs had much more freedom (e.g., of opinion, travel and religion). However, it was somewhat disconcerting that my interlocutors did not see any parallels with other socialist experiences.

During my fieldwork I realised that there still are great gaps of knowledge in regard to the crimes Tito committed, especially among young and middle-aged Bosniaks. There are few people who reflect on Tito's period of rule in a somewhat balanced way, taking note of the achievements of the former statesman as well as of the atrocities that were committed in his name. This phenomenon can be traced to the general lack of critical political and civic engagement with the socialist period compared to that which has taken place in other post-socialist countries, for example, in East Germany. Instead of a critical debate, nationalist propaganda prevailed in the immediate Yugoslav post-socialist years. To this day such a critical engagement has not yet been initiated since the crimes committed during the Yugoslav wars in the 1990s overshadow the crimes committed during socialist Yugoslavia (Gilbert 2006; Hosić 2014).

Although life in Yugoslavia cannot be compared to life in the Soviet Union, there was nevertheless a noticeable lack of democratic rights:

This was also connected to the fact that 'the people', in the sense of demos or plebs and as political subjects, have lost political influence and meaning in the Yugoslav constitutional system, while the nations and nationalities have become the main political subjects. (Stanovčić 1988: 26)

Its nations enjoyed more equality of rights in Yugoslavia than in any other socialist country, but there was a tremendous lack of universal democratic rights of individuals, uncoupled from the nation (Tepavac 2000: 76-77). This was one result of Tito's 'nationality politics' that gave more and more power to the republics. Cohen calls this new outlook of the 1960s 'pluralist socialism', a period when Tito realised that he could and should no longer treat intergroup conflicts as taboo (Cohen 1995: 29). 
During his rule, Tito had to juggle promoting brotherhood and unity and a shared Yugoslav identity ${ }^{7}$ (which he actively did only in the beginning) with giving in to national claims for more rights and autonomy in order to prevent revolution and secession. In the early 1960s leaders claimed more power at the level of the republics and increasingly rejected the concept of Yugoslav nationality. In the constitution of 1974, Tito finally awarded the republics more autonomy and power. With the constitutional changes in the 1970s, Yugoslavia moved from a centralised federal system to a confederal system (Cohen 1995). During the last decades of socialist Yugoslavia, people were also increasingly encouraged to identify themselves with a particular nation. For official purposes, such as census, citizens were discouraged from declaring their nationality as Yugoslav, but were pressured to choose one of the offered national categories. Parents in mixed marriages were advised to choose one of their nationalities rather than the category 'Yugoslav' when registering their children's births (see Denich 1993).

In order to counter the dominant nations (first and foremost the Serb and Croat), Tito promoted the national identity of smaller groups, including the Muslims. Before looking more closely at the rise of nationalism, let us first turn towards the question of the extent to which a supranational Yugoslav identity was accepted.

\section{National Identities and Nationality Politics}

In retrospect it is difficult to assess to what degree the citizens of Yugoslavia identified themselves as Yugoslavs. One source we can turn to in this matter is census data. When analysing such data, however, we should bear in mind that they only give a limited picture as identity issues in reality are complex, and multiple identities are likely to coexist. It may be safe to assume that the identity chosen in a census is often the one that is most politically useful. Furthermore, in order to interpret the choices made, we have to take into consideration the options given by the census. In the case of the Bosniak nation this is particularly important

\footnotetext{
${ }^{7}$ For a historical discussion of the idea of Yugoslavism, see Crampton (1997), Djokić (2003) and Djordjevic (1992).
} 
as Bosniaks were not able to choose their own nationality in any census before $1971 .^{8}$

At the beginning of the second Yugoslavia, Muslims chose the category 'Muslim undetermined' (read: religious Muslim of undetermined nationality) in the census of 1948 or 'Yugoslav undetermined' in the census of 1953 when the former option was no longer available. ' The census of 1961 gave Bosniaks the option to declare themselves as 'Ethnic Muslim'. Finally, in the census of 1971, they could identify as Bosnian Muslim by nationality (see Donia and Fine 1994; Lovrenović 1999). This late recognition of the Bosniak nation is remembered by Bosniaks — even by Tito-nostalgists—as one of Tito's greatest mistakes.

Starting from the assumption that group identities are situational and context-based, it is clear that census data, however precisely they are conducted, are never able to show the complexity of everyday identification. For example, a Herzegovinian woman with a Bosniak background may have stressed her Herzegovinian identity when travelling in Bosnia, her Bosnian (-Herzegovinian) identity when travelling in other republics of Yugoslavia, and her Yugoslav identity when travelling outside of Yugoslavia. If asked at home about her identity she may have referred to herself as Muslim. When not asked directly she may have presented herself as a Muslim, a Herzegovinian, a Bosnian (-Herzegovinian) and a Yugoslav in more or less the same terms, because these identities did not exclude one another.

National identity among many Croat Herzegovinians was more pronounced than among Bosniaks. While Croats in Bosnia have felt a stronger connection to $\mathrm{BiH}$ than to Croatia, in Herzegovina-owing to its geographical proximity to Croatia-Croats had stronger ties with Croatia. I have met Croats as well as Bosniaks who identify themselves as Herzegovinians; but I also noticed that for the former this was more than just a regional identity. In other words, the regional identity is not in addition to that of being a citizen of $\mathrm{BiH}$, but rather stands in opposition to it. In the cases of most of the several Croats I have met who stressed

\footnotetext{
${ }^{8}$ In February 1968 the Central Committee of the League of Communists of BiH decided to grant the Bosnian Muslims a nationality status recognised by the federal constitution (see Perica 2002: 75).

${ }^{9}$ In the early post-WWII censuses some Muslims also chose the census categories 'Serb' or 'Croat'.
} 
this, the emphasis on their Herzegovinian identity felt like a political statement declaring that if the Croats of Herzegovina could not be part of Croatia they could at least distinguish themselves from Bosniakdominated Bosnia (and perhaps in the future win a separate Croat entity). I experienced this position most strongly among HerzegovinianCroat academics who, when I said Bosna (Bosnia) instead of Bosna i Hercegovina (Bosnia and Herzegovina) for the sake of brevity, told me I always had to include Herzegovina because I would otherwise be making a political statement (see Žepić 2006).

In regard to questions of identification it was interesting to learn not only about my interlocutors' present identity but also about their pre-war identifications. Most told me that they have always identified themselves as 'Bosniak' or 'Croat'. Apart from a few exceptions, only those who still declare themselves as Yugoslavs told me about their former Yugoslav identification.

The percentage of cross-national marriages is often taken as proof that Yugoslavia overcame national cleavages. However, these numbers are interpreted very differently by different scholars of the region. Nikolai Botev and Richard Wagner (1993), for example, try to deconstruct the popular notion that national intermarriages increased during the postWWII socialist period. Their analysis is based on data from 1964 to 1988. It shows that mixed marriages were not as common as often assumed and constituted only $12 \%$ of marriages in Yugoslavia. 'The major finding from examining the resultant homogamy parameters is that endogamous, rather than exogamous, marriages remain the norm in Yugoslavia' (Botev and Wagner 1993: n.p.). However, in urban areas in $\mathrm{BiH}$, such as Mostar, mixed marriages were much more common and constituted around $30 \%$ of all marriages. The difference between rural and urban places is most likely linked to a process of increasing individualism in the latter: 'Interethnic marriages are justified in terms of individualism, and the idea of individual uniqueness contradicts ideologies of ethnic loyalty and tight ethnic incorporation' (Eriksen 1998: 130). This important factor helps explain why in cities, such as Mostar and Sarajevo, crossnational marriages were more common than in rural $\mathrm{BiH}$.

Moreover, we have to ask ourselves what the number of mixed marriages tells us. Is a low rate of such marriages necessarily a sign of a distance 
between the ethnic/national groups? Tone Bringa analyses the generally relatively low intermarriage rate in a somewhat more positive way. Although she agrees that (especially in rural areas) marriage within one's national group was a way to maintain group distinction, she does not conclude that this means an absence of tolerance or a rejection of the other group (Bringa 1993, see also Lockwood 1975). ${ }^{10}$ Mostar has had an exceptional position in Yugoslavia, which is also reflected in its incredibly high crossnational marriage rate. This does not mean, however, that cross-national marriages were the norm and that they were not contested (e.g., by older family members). But, in contrast to the present situation, they were socially more accepted during the post-WWII socialist period, at least in urban areas and were taken as proof that Tito's ideology of Brotherhood and Unity bore fruit.

Returning to Tito's nationality politics, it is significant that as early as the 1960s the LCY (League of Communists of Yugoslavia, Savez komunista Jugoslavije) stopped actively promoting the idea of Yugoslavism (Donia and Fine 1994: 177-178). This change in policy could also be seen in the media. Even though there were initial efforts to build a federationwide media crossing the borders of the respective republics-for example, the Yugoslavia-wide broadcast of the evening news Dnevnik each day in another republic - the majority of media outlets soon focused reporting and broadcasting on their own republic, resulting in the absence of a federation-wide media scene (Milošević 2000: 109). This phenomenon could also be observed in the case of radio programmes/stations and the print media (Allcock 2000: 293). Education, which together with the media is a central tool for creating a shared identity, was also organised on the level of republics. Since the republics were in control of the curriculum, the teaching of separate histories began even before the break-up of Yugoslavia, albeit in a diluted way (see Sekulic et al. 1994).

It can be concluded that initial hopes for a Yugoslav identity did not materialise, not even in $\mathrm{BiH}$. The resistance to forming a Yugoslav identity may be better understood in light of BiH's history, where all institutions

\footnotetext{
${ }^{10}$ This argument can be substantiated by the fact that in a peaceful and stable country like Switzerland, interethnic marriages are also not common. We should also consider that villages in $\mathrm{BiH}$ were often dominated by Bosniaks or Croats or Serbs.
} 
below the state were strongly tied to national affiliation, thereby preventing the development of a sense of citizenship (Allcock 2000: 277). The Bosnian political order structured along communitarianism has a long history. It can also be observed in the development of political parties that ostensibly represent the people of $\mathrm{BiH}$ but have actually been dominated by national factions since 1910 (Bougarel 1996: 87).

\section{Questions Around Coexistence (suživot) and Neighbourliness (komšiluk)}

Ottoman society, with its millet system, was constituted around religious groups who enjoyed semi-autonomy and who were ruled by their own religious leaders (Babuna 2004: 288). But even if 'communitarian' identities had structured political life in $\mathrm{BiH}$ since the Ottoman Empire (Banac 1993), what can we say about coexistence in everyday life? The quality of coexistence is much harder to measure than political agendas. Tone Bringa, who conducted research in a Bosnian village in the years before the recent war broke out, provides us with important observations that may help to explain the discrepancy. Bringa recognised that in social interactions, personality rather than nationality mattered (Bringa 1995: 151). This does not mean that nationality did not matter in the social structure of the village, but that in face-to-face contact it was the personality of the interlocutor that counted in the end. According to this interpretation, communitarism is a strong component of local politics, but is not necessarily reflected in everyday encounters among people of different national backgrounds. Hence, there is a discrepancy between practices in everyday life and those on the political level. I believe it is crucial to be aware of this tension between politics and everyday life in order to understand the complexity of national coexistence in $\mathrm{BiH}$, pre- and post-war (although in the latter there is far less room for cross-national interaction).

A central discourse about people's coexistence (suživot) is the concept of komšiluk (neighbourliness). If people speak about komšiluk when narrating the past, they are usually referring to the good pre-war neighbourliness. Even if Sorabji (2008) rightly reminds us that the concept of komšiluk cannot be reduced to cross-ethno-national relations, in discourses 
about the past it is usually referred to in this meaning. Komšiluk is then a way to express what was and what no longer is, and to emphasise today's corrupt relations between Bosniaks, Croats and Serbs. Pre-war komšiluk is narrated as the art of being neighbourly regardless of national affiliation (although Roma are usually excluded in this discourse), meaning neighbours who help each other out (for example, during illness) but who also celebrate festivities together and share daily practices, such as drinking coffee with one another (see Helms 2010; Stefansson 2010).

In post-war times, discourses on komšiluk often also centre on the urban-rural division (see Jansen 2005, see Chaps. 4 and 5). Aspects of komšiluk feature in narratives about the Yugoslav period among all three generations identified but are most prominent among the First Yugoslavs, whose narratives often centre on the decay of good neighbourliness and family life, as well as on the decay of urbanity in Mostar connected to the war (as a result of population change). But it is also a theme present in the narratives of the Post-Yugoslavs as well as the Last Yugoslavs. The latter are likely to follow a nostalgic discourse on komšiluk, even if they otherwise often draw strongly on a nationalist discourse.

Before more fully exploring how the past is narrated from the present position, it is important to attend to the exclusive nationalism that came to the forefront in the 1980s. In the following section, I briefly outline the national mobilisation of Croats and Bosniaks and discuss the role of clerics in this process. I first focus on the Croat national mobilisation before turning to that of the Bosniaks.

\section{National Mobilisation and Instrumentalisation of the Past}

The first great expression of a Croat national mass movement took place between 1967 and 1972 during the so-called 'Croatian Spring'. The movement's central demands were for more civil rights for Croat citizens and more decentralisation of the economy. Among Croats the belief was strong that Croatia would only reach Western Europe's level of prosperity without the rest of Yugoslavia. In the spring of 1971 the protests and strikes reached their peak and Croatia was on the verge of revolution. 
Tito threatened military intervention and jailed a large number of the movement's leaders and activists. In the subsequent period, the Roman Catholic Church took over the 'national agenda'. It started by reintroducing the cult of the Virgin Mary as the major national and religious symbol of Catholic Croatia: '[D]uring the Great Novena (1975-1984) the Croat episcopate carried out ethnic mobilization and religious awakening of Catholic Croats under the symbolic guidance of the Virgin Mary, referred to as the "Queen of the Croats"' (Perica 2002: 109). In 1981, six children from the village of Medjugorje (Western Herzegovina) stated that they had encountered a Croatian-speaking Madonna. Only seven years after the miracle had taken place, around 10 million people from all over the world had gone on pilgrimage to Medjugorje (see Bax 1995; Perica 2002; Sells 1996).

Perica (2002: 110) argues that the apparitions of the Virgin Mary at Medjugorje have to be understood in the context of the struggle of the Catholic Church with communism, the anti-communist backlash after Tito's death, and the deep economic crisis as well as the growing ethnopolitical tensions. The cult of the Virgin Mary and the mass pilgrimage to Medjugorje worsened the already tense relationship between the Catholic clergy and the Orthodox as well as Muslim representatives in $\mathrm{BiH}$. The last two groups viewed the Medjugorje movement as a fall-back into Ustashism, not least because Medjugorje was the headquarters of the Ustasha during WWII (see Bax 1995). ${ }^{11}$

Unlike their Christian counterparts, the Muslim clerics did not establish themselves as the guardians of national identity to the same extent. 'In contrast to Serbian and Croatian Christian clergy, Muslim clerics (hodžas, imams) and ulema did not systematically worship medieval native rulers, native saints, shrines, territory, and ethnic myths' (Perica 2002: 74). The top Muslim leaders were all Partisan veterans, and the loyalty of the ulema to the LCY was strong. But at the end of the 1980s nationalist goals found support among some anti-communist Muslim clerics who sympathised with Alija Izetbegović's religious nationalism. Increasing anti-Muslim sentiments made it easy for Izetbegović to present himself as the only defender of the Bosnian Muslim nation.

\footnotetext{
${ }^{11}$ To show their disapproval, but also to find another way to reach their nationalist goal, the Serbian Church started a year-long commemoration of the victims of WWII (see Perica 2002).
} 
Izetbegović had already been on the political scene in 1970 when he wrote the Islamic Declaration: A Program for the Islamization of Muslims and Muslim Peoples. In this declaration, he envisaged the Muslims of the world uniting to launch a religious and social revolution. Although not explicitly referring to Yugoslavia or $\mathrm{BiH}$, the text was critiqued by Izetbegovićs opponents who thought they could identify, embedded in the text, the claim that the Muslims, once they reached a majority, should establish an Islamic State. In 1983, the communists in power in Sarajevo took action by starting a massive propaganda campaign and arresting many of Izetbegovićs sympathizers. Izetbegović himself was sentenced to 14 years in prison (of which he served five years) because of his declaration (Meier and Ramet 1999; see also Hoppe 1998; Velikonja 2003). When the communists lost their influence, Izetbegović founded the leading Bosniak nationalist party SDA (Stranka demokratska akcije, Party of Democratic Action) in 1990 (see Babuna 1996; Perica 2002).

So, throughout the 1980s and in the beginning of the 1990s, Muslim identity (but also the identity of Croats and Serbs) was intensely discussed. A theory of common descent and a consistent Bosniak history was promoted. At the same time, however, Bosnian intellectuals revived the historical category Bošnjak (Bosniak) to include all three categories. This idea never succeeded. 'Since Serb and Croat national identification had won the day in Bosnia, Bošnjak had lost its meaning as an inclusive term for Bosnians of all three confessions' (Bringa 1995: 35). Bošnjak then became a synonym for Bosnian Muslim, in contrast to Croat and Serb. The reinventing of the term Bošnjak can also be seen as an attempt by Bosnian Muslims to establish a more obvious historical link to the state and territory of $\mathrm{BiH}$. At the same time the term Bosanac (Bosnian) as a regional identity for many people lost its meaning (Bringa 1995).

When national discourses became increasingly antagonistic, leaders of both the Bosnian Croats and the Bosnian Serbs loudly proclaimed that the Muslim population actually belonged to them (but they had merely converted to Islam, an argument already taken up earlier in history) and that they were only an 'invented people' (Bringa 1995; see also Ivanov 1996). When tensions intensified in the late 1980 s and early 1990 s, the 
Bosniaks were in an exceptional position since, unlike their Croat and Serb compatriots, their regional and national identities were more or less identical, given the fact that they did not have a 'mother country' (see Calic 1995a: 158). For this reason, Bringa (1995: 30) argues that the Bosniak identity was conceptualised differently than that of the Croats and the Serbs. Bringa states that the Bosniaks' collective identity was based on a shared environment, cultural practices and common experiences. In contrast, the collective identities of Croats and Serbs focused on shared blood and a myth of common origins.

In conclusion, we can say that a good number of clerics in $\mathrm{BiH}$ did act as carriers of the 'national idea', although the extent to which they became involved certainly differs and also changed over time. When nationalist politicians were not able to operate freely during Tito's rule and in many cases even were jailed, the churches (and to some degree also the mosques) took over and presented themselves as the only institutions capable of defending national interests. In the end, representatives from all three main religions in $\mathrm{BiH}$ fuelled tensions and mistrust.

The political involvement of religious representatives continued after the war, particularly before elections. In the 2006 pre-election period, for example, the Catholic Cardinal Puljić openly sided with the leading Croat nationalist party HDZ (Hrvatske demokratska zajednica, Croat Democratic Union). He made a plea to the Croat people to make their voices heard and to give support to those who were the only ones selflessly defending the interests of the Croat people, alluding to the HDZ (Slobodna Bosna, 8 September 2006). In a similar way, the religious head of BiH's Muslims, Reisu-l-ulema Mustafa ef Cerić made a plea to the Bosniak population to vote for the Bosniak nationalist party, which claimed to end the 'apartheid' in Mostar: 'We can see the establishment of Muslim ghettos in Mostar. Schools are divided and Bosniak children have to attend lectures in the evening hours. Unfortunately, we face apartheid in Mostar' (Danas, 13 July 2006). This speech by Cerić triggered a radicalisation of nationalist discourses on both sides and culminated in several violent acts that reinforced mistrust in Mostar. These incidents and the atmosphere of mistrust helped nationalist parties (of both sides) to gain votes. 


\section{War in Mostar and Its Aftermath}

It is a widely shared view that the break-up of Yugoslavia was launched 'from above' by an inductive nationalism rather than by a spontaneous process 'from below'. 'Its function was in all areas more or less two-fold: first to provide legitimacy to the old and new elites in their battle to maintain or obtain power, and second to replace old collectivism (communism) with a new form of collectivism (national homogenization)' (Pantic 2002: 78; see also Gagnon 2004; Gingrich 2002).

The fact that around 10,000 citizens participated in a peace march organised by the SDP (Socijaldemokratska partija, Social Democratic Party) in Mostar on 6 March 1992 shows that there was, at least initially, strong opposition to violence. As history showed, the conflict escalated the day after the peace march. ${ }^{12}$ For most of my interlocutors the war came to Mostar unexpectedly. At the time war broke out in Slovenia and Croatia, most people in $\mathrm{BiH}$ felt sure that their country would not be affected. Even when the war finally did break out in $\mathrm{BiH}$, many of my interlocutors still believed that Mostar would show resistance because it used to be the city known for its peaceful coexistence. This belief had serious consequences because families did not flee in time and children were not sent to safer places before the openly violent conflict soared. ${ }^{13}$

The following sections, focusing on Mostar's war and the aftermath, show that the war was the most 'efficient' means to achieve clear national cleavages; warmongers created (rather than drew on) clear-cut national identities in Mostar as elsewhere in $\mathrm{BiH}$.

\footnotetext{
${ }^{12}$ At this point it has to be pointed out that there were also 'positive stories' of neighbours helping each other out during the war, also across nations. One honourable project conducted by the Research and Documentation Centre (RDC) in Sarajevo is to collect these 'positive stories' by conducting oral history interviews with witnesses. I would like to thank the RDC staff for the time they granted me at their centre and for providing me with two 'positive stories', among other material, from Herzegovina, even if these interviews are not directly used in this book.

${ }^{13}$ For detailed analyses of the outbreak of the war in BiH, see Allcock (2000), Calic (1995b), Cohen (1995), Gagnon (2004), Meier and Ramet (1999), Melčić (2007), Ramet (2002), Ramet and Adamovich (1995).
} 


\section{The Course of the War in Mostar}

In contrast to analyses of the war that have attempted to explain the war fought on the territory of $\mathrm{BiH}$ between 1992 and 1995 as a single war, Bjelakovic and Strazzari (1999: 73) suggest we speak of a collection of local wars. ${ }^{14}$ When we look at post-war $\mathrm{BiH}$ from this perspective, it is not surprising to find a very diverse picture across different parts of the country. Owing to particular war experiences (including demographic changes of various kinds) different places in the country faced different post-war contexts.

When people in Mostar talk about the war, they most often speak about two wars. They refer to the war when Bosniaks and Croats fought as allies against the mainly Serb-dominated JNA (Jugoslovenska narodna armija, Yugoslav People's Army) as the 'first war' and to the war that then broke out between the former allies as the 'second war'. In the beginning of the war, the main military formations were the JNA and three types of Croat units: the HVO (Hrvatsko vijeće obrane, Croat Defence Council), the HOS (Hrvatske obrambene snage, Croat Defence Force) and the regular troops of the Croat Army. After numerous small-scale military conflicts, the first war started at the beginning of April 1992 between the Serbdominated JNA and SDS (Srpska demokratska stranka, Serb Democratic Party) troops on the one hand, and various Croat troops (HVO and HOS forces, including many Bosniaks among the latter ${ }^{15}$ supported by poorly armed units of the Territorial Defence (TO, loyal to the Sarajevo government) on the other hand. Because of the latter grouping's military marginality, the JNA, HVO, HOS and SDS forces remained the main actors.

When the war started, all healthy men aged 18-60 were banned from leaving the city. Despite this ban and the fact that Mostar was besieged (to the west and south by Croat-dominated troops and to the north

\footnotetext{
${ }^{14}$ The following overview of the course of the war in Mostar relies greatly on the article 'The Sack of Mostar, 1992-1994: The Politico-Military Connection' by Bjelakovic and Strazzari (1999), which provides a more detailed and balanced picture than most other literature on the Mostar war I am aware of (often written by former soldiers of one of the military forces involved). However, the description of the war events provided here makes no claim to be complete. More research on the course of the war is still needed.

${ }^{15}$ Many Bosniak conscripts and volunteers joined the HOS owing to the lack of any Bosniak military alternative.
} 
and east by Serb-dominated troops) people continued to leave the city (Bjelakovic and Strazzari 1999: 82). Owing to the lack of a unified command system for the different Croat-dominated forces and the TO, the JNA achieved control over most of the city. However, in May 1992 the HVO assumed full military power and the JNA began to withdraw from $\mathrm{BiH}$, but left $80 \%$ of its personnel and nearly all its military equipment to the new VRS (Vojska Republike Srpske, Army of the Serb Republic). During the months of withdrawal, most of the Serb population fled the town and settled in eastern Herzegovina in places such as Bileća, Trebinje, Gacko and Nevesinje, or fled to Serbia and Montenegro. Even though the VRS had withdrawn, it maintained control over the surrounding hills where it stationed its artillery (see Bjelakovic and Strazzari 1999; Yarwood 1999).

As soon as the former enemy left the city, a power struggle began among the former allies (Bosniaks and Croats). With the sudden retreat of the Serb troops, rumours persisted that Serbs and Croats had agreed on a secret deal to divide $\mathrm{BiH}$ between them at the Geneva talks. Even before war between the former allies had begun, there were signs that $\mathrm{HDZ} \mathrm{BiH}$ was already preparing for secession:

On 3 July 1992 the Croat Community of Herceg-Bosna (HZ HercegBosna) was proclaimed. Already in this founding document Mostar was listed as the capital of the community. With this the town, the population of which was only to some one third Croat, attained a paramount importance in the thinking of Bosnian Croat separatists. They claimed that both Serbs and Bosniacs had their own towns. Mostar was to be theirs. (Gosztonyi 2003: 132)

In August 1992, Bosniak soldiers in the HOS units were disarmed and expelled or brought to detention camps. In this mutual climate of distrust and with the refusal of the HVO to enter into a joint command with the $\mathrm{TO}$, the Bosniak-dominated Army of Bosnia and Herzegovina $(\mathrm{ABiH}$, Armija Bosne i Hercegovine) was formed.

The Croats claimed their right to a Croat (West) Mostar by arguing that it was the only Croat city in $\mathrm{BiH}$ (Sarajevo being Bosniak and Banja Luka, Serb) and that if they lost it the Croat nation would not 
be viable (see Yarwood 1999: 5). In order to mobilise Croats, an antiMuslim propaganda campaign was launched with the active participation of Mostar's Croat TV station 'HTV'. The Bosniaks were presented as betrayers, as in this statement by Mate Boban, president of Herceg-Bosna and leader of the HVO:

It is simply incomprehensible and difficult to understand that those who have survived thanks to the Croatian people and the Croatian units [...] those who have gained their strength their breath of life, thanks to Croats-have now turned against the Croats. (Mate Boban cited in Cohen 1995: 252)

Both this and similar statements fell on fertile soil after the military success of the $\mathrm{ABiH}$ against the $\mathrm{HVO}$ during the autumn of 1993, when thousands of civilian Croats in central Bosnia were killed or forced to flee (Cohen 1995: 279).

According to Bjelakovic and Strazzari (1999) there are two factors that contributed to the ultimate military confrontation between Croat and Bosniak forces in May 1993. Firstly, the HVO changed its character from a military organisation to an administrative-political unit, which became the backbone of the proclaimed Herceg-Bosna. Mostar was the most important city in $\mathrm{BiH}$ for the Croat goal to establish a mini Croat state- - HercegBosna - within $\mathrm{BiH}$, with future aspirations to annex it to Croatia proper. The second factor contributing to the escalation of the conflict was the prospect that $\mathrm{BiH}$ would eventually be divided along national lines following the Vance-Owen plan which proposed the dividing of the country into several provinces (Bjelakovic and Strazzari 1999: 85; see also Cohen 1995).

Until May 1993 the relationship between the Bosniak-dominated $\mathrm{ABiH}$ and the Croat-dominated $\mathrm{HVO}$ remained tense but relatively calm, even if at that time the two armies had started fighting regularly in Central Bosnia. But on 2 May 1993, the HVO imposed a blockade and snipers shot at people trying to cross from the Croat-dominated west part of the city to the Bosniak-dominated east part. Seven days later the HVO launched a full-scale attack on $\mathrm{ABiH}$-held territories. The $\mathrm{ABiH}$ was seemingly not prepared for defence. Witnesses reported that the majority of attackers were Croats from Croatia. This was seemingly confirmed 
when the attackers became lost in the little streets of Old Town during the course of an attack they had themselves launched. But as Gosztonyi (2003) points out, and as I experienced during my stay in Mostar, there is also a Croat version of the outbreak of the Bosniak-Croat war. In this Croat version the $\mathrm{ABiH}$ launched a night offensive, which was only then answered by a Croat counter-offensive.

Even though the HVO became stuck in the city centre, it managed to completely encircle the Bosniak-held part of Mostar. The HVO used tactics similar to those of the VRS in Sarajevo (Gosztonyi 2003: 133), including the intensive use of sniper fire. Besieged, East Mostar was under bombardment by heavy artillery and inhabitants faced a lack of supplies of food, electricity, medicine and so on. Relief convoys did not get through to East Mostar, which in the preceding seven weeks had been cut off from any international presence and humanitarian aid. Thereafter the population of Mostar was supplied with food by relief convoys and by US aircraft, which dropped food over the besieged territory. This experience and the food that was provided still remains a central wartime memory for those who remained in Mostar during the war.

The siege also meant that the $\mathrm{ABiH}$ in Mostar was disconnected from other $\mathrm{ABiH}$ units in the country and from arms supplies. This resulted in the bizarre (but not uncommon) situation of Serbs in the surrounding hills selling their firearms to the $\mathrm{ABiH}$. On the frontline-the Bulevar, which was perceived as no-man's-land-Bosniak and Croat soldiers were separated only by a few metres. Across such a short distance, the fighters-some of them former schoolmates, neighbours or friends-were sometimes even able to recognise one another when firing from the other side. Throughout the 10 months of the Bosniak-Croat war, the frontline remained quite stable (see Bose 2002). The situation around the Bulevar is only one example of the immediacy of the war fought in $\mathrm{BiH}$ (see Sorabji 1995).

The Bosniak side had less heavy artillery and as a consequence was surrounded and suffered the highest number of casualties in Mostar. However, the $\mathrm{ABiH}$ launched several offensives against $\mathrm{HVO}$ positions. From Jablanica and Konjic it succeeded in pushing back the HVO in a southern and south-western direction. At the same time, operations were launched from Mostar by the ABiH Fourth Corps (Gosztonyi 2003: 139). Finally, Mate Boban was dismissed when his war against the Bosniak 
population was no longer supported by the Croat leadership. He had to resign in February 1994. Shortly afterwards a ceasefire agreement was reached between the warring parties. This was achieved within sight of the Washington Agreement signed on 3 March 1994:

When the firing ended ten months later with the Washington Agreement (March 1994) establishing the Muslim-Croat Federation in BiH, Mostar was unrecognizable. The frontline had cut through the town centre, with Croat and Bosniac positions usually no more than twenty to thirty feet apart, often on two sides of the same street. (Bose 2002: 104)

Although peace had (officially) been achieved, the war had left a visible mark on the city and its people (CMMSM 2004).

\section{A City Left Divided}

With the Dayton Peace Agreement, signed on 14 December 1995, the 43-month-long war in $\mathrm{BiH}$ officially ended. From that day on, $\mathrm{BiH}$ became a shared state of the three constituent peoples-Bosniaks, Croats and Serbs_-with Sarajevo as the remaining capital. But the country was split into two entities (and the special district of Brčko): the Serb Republic and the Federation of $\mathrm{BiH}$ with its 10 cantons. The Washington Agreement that established the Federation of $\mathrm{BiH}$ (which comprises $51 \%$ of BiH's territory as opposed to the Serb Republic constituting 49\%) foresaw Mostar as a united Bosniak-Croat city and as the capital of the Herzegovina-Neretva Canton (Canton 7). Together with the Central Bosnia Canton (Canton 6), both cantons were the only mixed Bosniak-Croat cantons. BiH became a decentralised state consisting of a complicated bureaucracy and an economically untenable government with multiple layers of decision-making. The situation was further complicated by the far-reaching powers of the so-called 'international community' ${ }^{16}$ (see Chandler 2000; Dzihic 2010). The Dayton Peace Agreement put into place an international peacekeeping force to ensure security in the country and an international authority, the Office of the High Representative (OHR), to implement the civilian

\footnotetext{
${ }^{16}$ I use the term 'international community' in the manner that it is commonly used to refer to the various (military and civilian) international organisations active in $\mathrm{BiH}$.
} 
dimension of the peace agreement. As will be discussed below, the OHR was a key player in post-war developments in Mostar.

During the war all 10 bridges in Mostar were destroyed by either the Serb or Croat forces, and only temporary structures were built for people to cross to the other riverbank. In the immediate post-war period, citizens of both the eastern and the western parts were not allowed to cross freely between sides, and there was only one crossing point, which provided restricted access for women and children only. During this time, the eastern part still suffered from food, water and electricity shortages, and there were no jobs for people as most of the factories had been destroyed. Overall, the expulsion of non-Croats from West Mostar also continued (see ICG 2000). Until 1997, people were still being wounded and killed by grenades and expelled from their homes although the war was officially over. One such violent episode often remembered among Bosniaks is the fatal incident that took place on 10 February 2007 during Bajram festivities. A group of Bosniaks who visited a cemetery in West Mostar were attacked by the West Mostar police. One person (the husband of a woman I met at Otvoreno srce) died and several others were wounded.

The situation meant minority return remained a critical issue in Mostar for years after the war had ended. Annex Seven of the Dayton Peace Agreement, 'Agreement of Refugees and Displaced Persons', ensures the right of all refugees and displaced persons to return freely to their homes of origin. Nonetheless, Mostar's authorities delayed the processing of claims by minority members to return to their pre-war residences. In West Mostar, the Veterans Association HVIDR-a (Hrvatski vojni invalidi domovinskog rata, Croat War Invalids of the Homeland War) tightly controlled the housing stock and minority return did not fit with their aim of keeping West Mostar an exclusively Croat city. Likewise East Mostar was a hostile place for Croats in the immediate post-war years.

Between 1992 and 1995 around 2.2 million persons were forcibly displaced from their homes in the territory of today's $\mathrm{BiH}$. Of these 2.2 million, around 1.2 million fled the country while around 1 million remained in $\mathrm{BiH}$ (see Kappel et al. 2006). ${ }^{17}$ Before the war, Mostar had

\footnotetext{
${ }^{17}$ 'It is estimated that about 440,000 refugees have returned from abroad, 720,000 have settled in their host countries, and about 100,000 are still in need of durable solutions. Of the one million IDPs about 700,000 have either returned to their pre-war homes or settled at other places in the country, while some 300,000 people are estimated as still being internally displaced' (Kappel et al. 2006: 9).
} 
a population of 126,628 with $34.8 \%$ Muslims, $33.8 \%$ Croats and 19 $\%$ Serbs (Koschnick and Schneider 1995: 12). Presently, Mostar has around 111,000 inhabitants split almost equally between Bosniaks and Croats. Most of the Serb population (around 20,000) fled before the war between $\mathrm{HVO}$ and $\mathrm{ABiH}$ escalated, leaving only a small number of around 2000 Serbs who remained (or returned) to Mostar. Among those who left Mostar was a large part of the intelligentsia as well as middle-class professionals.

In 1998 and the years thereafter, the United Nations High Commissioner for Refugees (UNHCR) and the American Refugee Committee (ARC) promoted a so-called 'driven return process'. In those years, potential returnees were offered financial incentives to return. These funds are now exhausted and there is only some 'spontaneous return' to Mostar. ${ }^{18}$ Even those who returned to Mostar did not necessarily return to their pre-war homes. Instead, many flats were exchanged (or sold), especially between Croats and Bosniaks. Generally, elderly people of all three nationalities were more likely to move back to their old homes even if they were faced with the situation of being in the minority.

My elderly interlocutors felt strongly attached to their (pre-war) homes and preferred to return to them over moving to another part of the city. Although they expressed grief over missing their old neighbourhood (komšiluk), they still preferred to return to (or remain in) their former flats or houses (see Chap. 4). Their children, however, preferred to exchange or sell their old homes in order to live on the side where they were in the majority. For some Mostarians, it was simply no longer conceivable to live in West Mostar because of the violence they had experienced there. This was the case for a Bosniak family I got to know during my stay, whose male family members had spent from several months to more than a year in different Croat detention camps. After this experience, they had to sell their houses since they no longer felt free to return.

Only a small number of the pre-war Serb population returned to Mostar. Most stayed outside the city to the north and south of it, not least because it was economically easier for them than in Mostar itself.

\footnotetext{
${ }^{18}$ I obtained the information on refugees and the return process during interviews with staff from the UNHCR Mostar field office.
} 
Unlike Bosniak and Croat politicians who encouraged co-nationals to return to Mostar in order to maintain or attain majority status, Serb politicians who claimed that Mostar was-like the Federation in general-a hostile place for Serbs discouraged Serbs from returning. Moreover, they argued that children would not be able to keep their Serb identity, for example, because of the Bosniak-Croat-dominated education system in Mostar. Even if returnees today no longer face security issues, and military or police patrols in returnee areas are no longer necessary, they may still face discrimination, for example, through insulting statements in the media or from ignorant teachers in school. They may also feel unwelcome when confronted with insulting graffiti (Fig. 2.1) or, in the case of West Mostar, by the renamed streets and public places (Palmberger 2013).

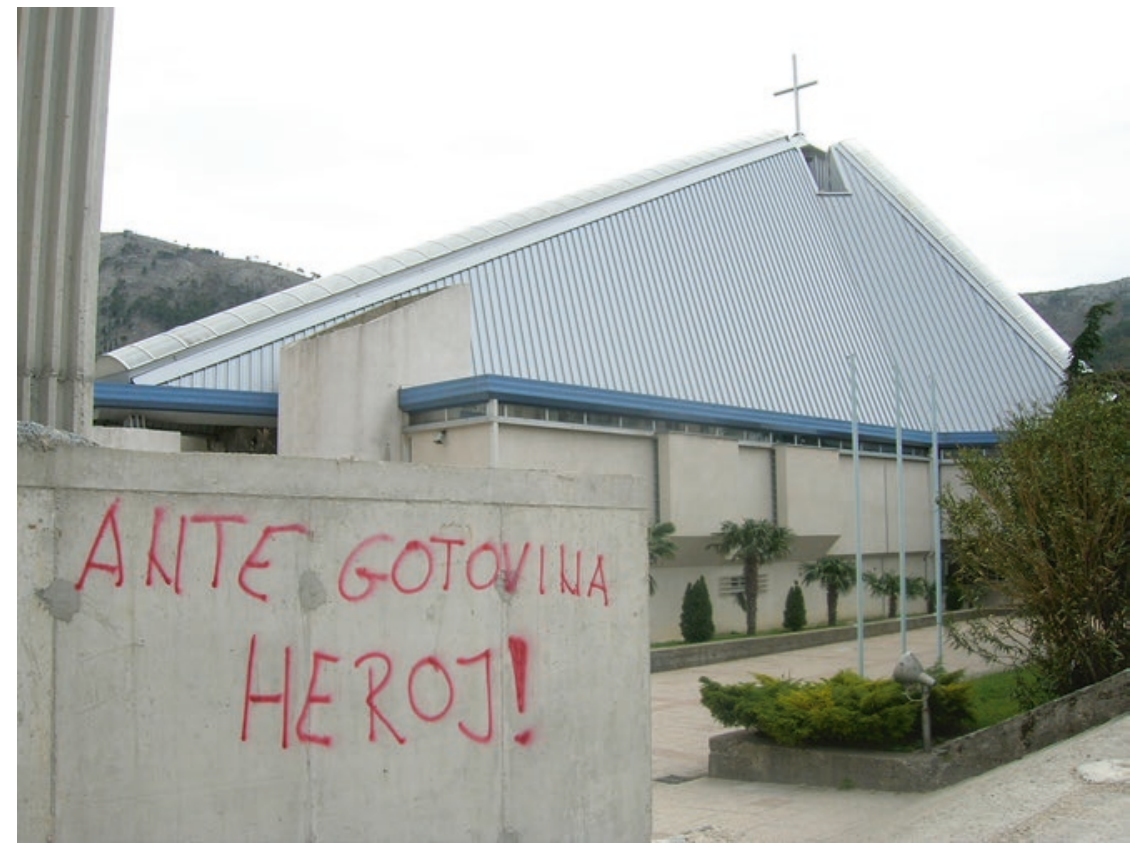

Fig. 2.1 Graffito next to the Catholic cathedral stating: 'Ante Gotovina heroj' ('Ante Gotovina is a hero'). This graffito appeared at several places in West Mostar in December 2005 when Gotovina, a Croat general, was arrested by the International Criminal Tribunal for the Former Yugoslavia (ICTY). Photo by the author 


\section{The Process of Unifying Mostar}

For the first 10 years after the war ended, the HDZ was a strong opponent of a reunified Mostar. As discussed earlier, Mostar was seen as the only Croat city in $\mathrm{BiH}$. Ideological as well as personal and economic interests factored into this stance. The absence of the state and the proliferation of illicit activities helped to serve personal economic interests (see ICG 2000: 2; see also Bjelakovic and Strazzari 1999: 92).

Unlike Croat politicians, Bosniak politicians initially supported the idea of Mostar's reunification. However, according to a report by the International Crisis Group (ICG) (ICG 2000) this was only so long as the Bosniak population in Mostar formed the numerical majority. In this respect, they shared the interests of the international community for whom the reunification of Mostar presented the only post-war solution and was seen as crucial for future development in BiH (see ICG 2000).

In the first six years after the war, the international community invested hundreds of millions of Euros in reuniting the city. The European Union (EU) alone spent approximately 200 million Euros (see ICG 2000). But the investment did not produce the results the international community had hoped for. Analysing the international post-war engagement in Mostar, Bieber (2005) reaches the following conclusion:

Ironically, the international presence reinforced the division between Bosniac and Croat parts of town. [...] Rather than challenging the ethnic division of the city, the rigid power-sharing system-instituted by the international administrators-both accepted and perpetuated the post-war status quo. (Bieber 2005: 424)

The ICG came to a similar conclusion in its report when it accused the international community of having directly contributed financial aid to ethnically controlled municipalities rather than to the central administration (see ICG 2000).

Reflecting the Dayton Peace Agreement's purpose as a cease-fire agreement, the new municipal boundaries were drawn on the basis of the distribution of forces, not on economic, social or historical criteria. The city itself was divided into six municipalities, three Bosniak and three 
Croat, with a small central zone to be administered by the joint city government. However, the EU reduced the size of the central zone following riots and attacks against Hans Koschnik, the first EU administrator, by supporters of the HDZ. This concession in the face of violent resistance undermined international efforts in Mostar for years to come (Bieber 2005: 422).

As early as June 1996, the first post-war election for the municipal and city government took place. Unsurprisingly, the votes were split among the two major parties: HDZ and the Citizen's List (a coalition party including the SDA), with the former winning $45 \%$ of the votes and the latter $48 \%$ (see Tomić and Herceg 1999). The two parties led opposing election campaigns. The Citizen's List advocated the unification of the city, while the HDZ was in favour of leaving the city divided to ensure West Mostar remained the Croat capital of BiH (see ICG 2000).

With the Interim Statute imposed in 1996, the EU administration sought to install power-sharing mechanisms so that no community could gain an outright majority. Without the cooperation of local politicians, however, this power-sharing system was doomed to fail:

The leading Bosniac and Croat parties (the SDA and HDZ respectively) sought to get round the ethnic quota system by placing Serb (or other) candidates on their party electoral lists and thereby managed to 'capture' from non-dominant communities, resulting in vacant seats. (Bieber 2005: 423)

The city government, with a mayor and deputy mayor (in a rotating system, one of them Bosniak, one Croat), was performing poorly. Instead of jointly governing the city, the mayor and his deputy governed only their 'own' side of Mostar and city institutions ran in parallel. Another central problem was the veto right of the Bosniak and Croat nations, which could be used when 'fundamental interests' were endangered. Since national fundamental interests could be widely interpreted, the veto right was extensively misused to block decisions (Bieber 2005: 423).

In this political climate, the city was left separated in all aspects of life: politically, economically (e.g., parallel tax systems), culturally and also in terms of healthcare, education, the media and jurisdiction (see Bose 2002; ICG 2000). In Mostar everything was (and to some extent still is) duplicated. The city had two mobile phone providers, two post 
offices, two electrical distribution companies, two public pension funds, two hospitals including two ambulance services, two bus companies and two main bus stations, two water and sewage companies, two companies for city cleaning and, of course, two football clubs (see ICG 2000, 2003).

The city's unification proved to be harder than expected and reflected badly on the international community, which by 2004 (after almost 10 years) had achieved little progress on the matter. So a new and permanent statute was sought that would finally require that Serbs and 'others' enjoy an equal status in Mostar's government and administration. Because the Interim Statute was aligned for the two main actors, Bosniaks and Croats, it no longer met the constitutional amendments on the entity level in 2002. For these reasons, from 2003 onwards Mostar received renewed attention from the international community and became Paddy Ashdown's (High Representative between 2002 and 2006) priority. According to a report by the ICG (ICG 2009), at this time a notable shift took place in the attitudes and agendas of the main political actors in Mostar, the HDZ ${ }^{19}$ and SDA. The two parties seemed to have swapped their positions. Surprisingly, the HDZ expressed enthusiasm for unifying the city, while SDA became reserved and defended the status quo. Since this change in strategy, the Bosniak and Croat parties' struggles have run contrary to those of their party representatives operating at the state level.

Although there was confusion about this turnaround, the reason for it, as given by the ICG (2009), is simple: the demographic composition had changed whereby Bosniaks had lost their majority status in Mostar. Therefore the SDA now feared subordination by Croats, while the HDZ were eager to unify Mostar once they had overtaken the formerly dominant national group, the Bosniaks. ${ }^{20}$

After months of unsuccessful negotiations, the new city statute was finally imposed by the High Representative Paddy Ashdown in 2004. Although power-sharing rules were no longer as rigid, the new statute guaranteed national equality. The unification seemed to signal a final breakthrough towards normalisation. Even if a unified administration had not quite been realised, it could still be seen as a first step towards the city's reunification.

\footnotetext{
${ }^{19}$ In 2006 the HDZ split into the 'HDZ' and the new 'HDZ 1990'.

${ }^{20}$ The new population figures from the national division in Mostar were a rough estimate from the list of registered voters made public by the $\mathrm{BiH}$ Electoral Commission. The ICG estimated the division to be around $58 \%$ Croats, $40 \%$ Bosniaks and 1.5 \% Serbs (ICG 2003: 7).
} 
Through this move, more spaces of mutual interaction were created-for example, more civil servants of different backgrounds sharing a workplace.

Mostar's citizens are generally tired of the endless quarrels among local politicians. Most long for what they call a normalan život (normal life), which refers first and foremost to better living conditions (jobs, education, city services and so on) (see Jansen 2015). In many respects, the unification of Mostar has only been superficial while in reality deep divisions remain. This is true, for example, of public services, which remain inefficient and costly. Even where the unification of public services has been officially achieved, the services are still provided along the lines of the old division. Presently Mostar faces the situation where services run under the same name but are operated separately (ICG 2009: 4). Rather than believing that politicians represent them and their needs, Bosniaks and Croats alike blame their respective politicians for being primarily concerned with their own privileges.

Five years after the official unification, in 2009, Mostar's citizens were once more certain that the path to normalisation in Mostar remained long. More than a year after local elections Mostar's politicians were still unable to elect a mayor (who is indirectly elected by the city council), having missed more than a dozen occasions to do so. This failure had far-reaching consequences for many people, as for many months employees of publicly owned companies as well as Mostar's civil servants were not paid their salaries. A friend from Mostar reported to me the following via e-mail:

Mostar still doesn't have a mayor... and there is no prospect that we will get one any time soon. [...] We could win the Guinness [book of] records with this situation since it will be one year in less than a month. The general state in the state is really awful and it is getting worse every day with all these political disputes and new threats of war... but I'm ignoring it... what can I do? : - )

This e-mail reflects very well how many Mostarians deal with the political quarrels in their city. Of course they take notice but face it with a kind of (black) humour. My friend's statement 'but I'm ignoring it' cannot be taken literally since in the e-mail she reports on the issue she claims to ignore. It can instead be understood as an attempt to keep these issues away from her private life. Many of my informants told me that they had stopped reading local newspapers or watching the local evening news because they just do not want to deal with it any longer. Whether such 
claims can be taken literally or not, I do not know, but nevertheless they are expressions of strong disapproval with local politics.

Since the day the leading Croats in Mostar learned there was a Croat majority in the city, they have demanded not only a united administration but also one that runs on equal terms with other city administrations in $\mathrm{BiH}$ : 'Croats point out that Mostar is the only city with a Croat majority and the only city in which the ethnic majority is limited by statute to a minority of council seats, so unable to elect a mayor on its own' (ICG 2009: 7). Bosniak politicians, on the other hand, insist on Mostar's exceptional position due to their nation's troubles during the war years, and they appeal to their pre-war majority position. They also blame Sarajevo for caring too little about Mostar, which they say is in danger of being taken over by Croats. In addition, they blame the capital for its limited financial investment in East Mostar. The unequal financial support for East and West Mostar, with the latter being supported by Croatia, is clearly visible in the cityscape.

\section{Reopening of the Old Bridge}

The year 2004 was a year of reunification in Mostar, at least symbolically; the city was officially reunified with a shared administration and city council, but international media reports mostly focused on the reconstruction and reopening of the Old Bridge (Stari most) that took place the same year (Fig. 2.2).

The old Ottoman Bridge that had been destroyed in 1993 was finally reconstructed in 2004 with the financial help of United Nations Educational, Scientific and Cultural Organization (UNESCO) and the World Bank. The reconstruction of the bridge with its grandiose reopening celebration carried a lot of symbolic meaning. Ten years after the war had ended in Mostar, the international community needed a showpiece of success to signal that the reconciliation process had progressed. In his lecture at the Examination Schools in Oxford on 23 July 2004, Paddy Ashdown spoke of the reopening of Mostar's Old Bridge as a symbol that civilisation had prevailed over barbarism and that it was a clear sign of goodwill for a new start of multinational coexistence in Mostar. This assessment is not shared by all experts on $\mathrm{BiH}$ (see, for example Bougarel et al. 2007; Hoare 2004). 


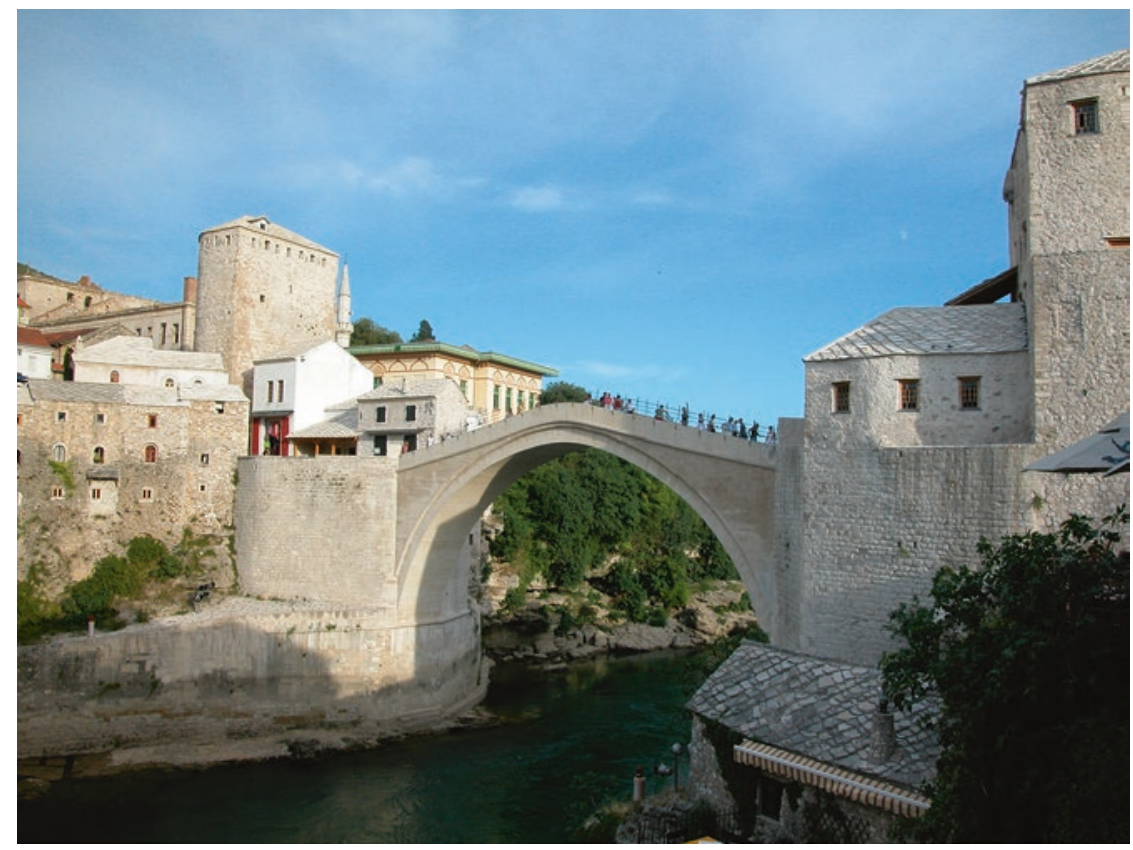

Fig. 2.2 Rebuilt Stari most (Old Bridge). Photo by the author

Bosniaks and Croats differed on the importance of the reopening of the Old Bridge. While most of my Bosniak informants, who were in Mostar at the time of the celebration, joined the event, most of the Croats did not. Since the Croat army, the HVO, is considered by Bosniaks, as well as by the international community, to be responsible for the final destruction of the bridge (after numerous shells fired by the Croat and Serb army had damaged it), Croats often take a defensive position when the subject of the Stari most comes up. Although I do not wish to question the reconstruction of the bridge, it is still not clear to what extent it has had an impact on the reunification of Mostar. Moreover, although often unmentioned, the Old Bridge does not connect the Bosniak and Croat parts of the city (which are divided by the Bulevar west of the bridge). ${ }^{21}$

\footnotetext{
${ }^{21}$ Stari grad (Old Town), where the bridge is located, made it onto the World Monuments Fund list of the 100 most endangered sites of historical and cultural significance (Grodach 2002: 66).
} 


\section{Bibliography}

Allcock, John B. 2000. Explaining Yugoslavia. New York: Columbia University Press.

Assmann, Jan, and John Czaplicka. 1995. Collective Memory and Cultural Identity. New German Critique 65: 125-133.

Babuna, Aydin. 1996. Die nationale Entwicklung der bosnischen Muslime: Mit besonderer Berücksichtigung der österreichisch-ungarischen Periode. Frankfurt/Main: P. Lang.

- 2004. The Bosnian Muslims and Albanians: Islam and Nationalism. Nationalities Papers 32(2): 287-321.

Banac, Ivo. 1993. The National Question in Yugoslavia: Origins, History, Politics. Ithaca: Cornell University Press.

Bax, Mart. 1995. Medjugorje: Religion, Politics and Violence in Rural Bosnia. Amsterdam: VU.

Bet-El, Ilana R. 2002. Unimagined Communities: The Power of Memory and the Conflict in the Former Yugoslavia. In Memory and Power in Post-War Europe: Studies in the Presence of the Past, ed. J.-W. Müller, 206-222. Cambridge: Cambridge University Press.

Bieber, Florian. 2005. Local Institutional Engineering: A Tale of Two Cities, Mostar and Brcko. International Peacekeeping 12(3): 420-433.

Bjelakovic, Nebojsa, and Francesco Strazzari. 1999. The Sack of Mostar, 19921994: The Politico-Military Connection. European Security 8(2): 73-102.

Bose, Sumatra. 2002. Bosnia after Dayton: Nationalist Partition and International Intervention. London: Hurst \& Company.

Botev, Nikolai, and Richard Wagner. 1993. Seeing Past the Barricades: Ethnic Intermarriage in Yugoslavia During the Last Three Decades. Anthropology of East Europe Review 11(1-2). http://condor.depaul.edu/ -rrotenbe/aeer/ aeer11_1/botev.html [17.07.2009].

Bougarel, Xavier. 1996. Bosnia and Herzegovina - State and Communitariansim. In Yugoslavia and After: A Study in Fragmentation, Despair and Rebirth, eds. D.A. Dyker and I. Vejvoda, 87-112. London: Longman.

Bougarel, Xavier, Elissa Helms, and Gerlachlus Duijzings. 2007. Introduction. In The New Bosnian Mosaic: Identities, Memories and Moral Claims in a PostWar Society, eds. X. Bougarel, E. Helms, and G. Duijzings, 1-35. Aldershot: Ashgate.

Bringa, Tone. 1993. Nationality Categories, National Identification and Identity Formation in "Multinational" Bosnia. Anthropology of East Europe Review 11 
(1-2). http://condor.depaul.edu/ rrotenbe/aeer/aeer11_1/bringa.html [17.07.2009].

-1995. Being Muslim the Bosnian Way: Identity and Community in a Central Bosnian Village, Princeton Studies in Muslim Politics. Princeton, NJ: Princeton University Press.

Brown, Keith. 2003. The Past in Question: Modern Macedonia and the Uncertainties of Nation. Princeton, NJ: Princeton University Press.

Calic, Marie-Janine. 1995a. Ethnische Konflikte in Bosnien-Herzegovina. Eine strukturelle Analyse. In Minderheiten als Konfliktpotential in Ostmittel- und Südosteuropa, ed. G. Seewann, 154-173. Munich: R. Oldenburg Verlag.

—.1995b. Der Krieg in Bosnien-Hercegovina: Ursachen-Konfliktstruktureninternationale Lösungsversuche. Frankfurt/Main: Suhrkamp.

Carmichael, Cathie. 2002. Ethnic Cleansing in the Balkans: Nationalism and the Destruction of Tradition, Routledge Advances in European Politics. London: Routledge.

Chandler, David. 2000. Bosnia: Faking Democracy after Dayton. 2nd ed. London: Pluto Press. Original edition, 1999.

CMMSM. 2004. Mostar, Urbicid. Mostar: Centar za mir i multietničku saradnju Mostar (CMMSM).

Cohen, Lenard. 1995. Broken Bonds: Yugoslavia's Disintegration and Balkan Politics in Transition. 2nd ed. Boulder: Westview Press. Original edition, 1993.

Cohen, Philip J., and David Riesman. 1996. Serbia's Secret War: Propaganda and the Deceit of History. College Station: Texas A\&M University Press.

Crampton, Richard J. 1997. Eastern Europe in the Twentieth Century - And After. London: Routledge.

Denich, Bette. 1993. Unmaking Multi-Ethnicity in Yugoslavia: Metamorphosis Observed. Anthropology of East Europe Review 11(1-2). http://condor.depaul. edu/ rrotenbe/aeer/aeer11_1/denich.html [17.07.2009].

- 1994. Dismembering Yugoslavia: Nationalist Ideologies and the Symbolic Revival of Genocide. American Ethnologist 21(2): 367-390.

Djokić, Dejan. 2003. Yugoslavism: Histories of a Failed Idea, 1918-1992. London: Hurst \& Company.

Djordjevic, Dimitrije. 1992. The Yugoslav Phenomenon. In The Columbia History of Eastern Europe in the Twentieth Century, ed. J. Held, 306-344. New York: Columbia University Press.

Donia, Robert J., and John Fine. 1994. Bosnia and Hercegovina: A Tradition Betrayed. London: Hurst. 
Dyker, David A. 1990. Yugoslavia: Socialism, Development and Debt. London: Routledge.

Dzihic, Vedran. 2010. Ethnopolitik in Bosnien-Herzegowina: Staat und Gesellschaft in der Krise. Baden-Baden: Nomos.

Eriksen, Thomas H. 1998. Common Denominators: Ethnicity, Nation-Building and Compromise in Mauritius. Oxford: Berg.

Gagnon, Valere P. 2004. The Myth of Ethnic War: Serbia and Croatia in the 1990s. Ithaca, NY: Cornell University Press.

Gilbert, Andrew. 2006. The Past in Parenthesis: (Non) Post-Socialism in PostWar Bosnia-Herzegovina. Anthropology Today 22(4): 14-18.

Gingrich, Andre. 2002. When Ethnic Majorities Are 'Dethroned'. Towards a Methodology of Self-Reflexive, Controlled Macrocomparison. In Anthropology, by Comparison, eds. A. Gingrich and R.G. Fox, 225-248. New York: Routledge.

Gosztonyi, Kristóf D. 2003. Verhandlungsführung in humanitären Interventionen am Beispiel der internationalen Intervention in den Krieg in BosnienHerzegowina. Dissertation, Political Science, FU Berlin.

Grodach, Carl. 2002. Reconstituting Identity and History in Post-War Mostar, Bosnia-Herzegovina. City: Analysis of Urban Trends, Culture, Theory, Policy, Action 6(1): 61-82.

Hayden, Robert. 1994. Recounting the Dead. The Rediscovery and Redefinition of Wartime Massacres in Late- and Post-Communist Yugoslavia. In Memory, History, and Opposition under State Socialism, ed. R. Watson, 167-189. Santa Fe, NM: School of American Research Press.

Helms, Elissa. 2010. The Gender of Coffee: Women and Reconciliation Initiatives in Post-War Bosnia and Herzegovina. Focaal 57: 17-32.

Hoare, Marko A. 2004. The Bridges of Bosnia. In Bosnia Report No. 41, ed. Q. Hoare. London: Bosnian Institute. http://www.bosnia.org.uk/bosrep/ report_format.cfm?articleid=1125\&reportid=165 [20.06.2010].

2005. Genocide and Resistance in Hitler's Bosnia: The Partisans and the Chetniks, 1941-1943. Oxford: Oxford University Press.

Hoppe, Hans-Joachim. 1998. Das Dayton-Abkommen und die neue Führungselite in Bosnien-Hercegovina. Bundesinstitut für ostwissenschaftliche und internationale Studien. Cologne. http://www.ssoar.info/ssoar/View/?resid=4344 [15.05.2010].

Hosić, Aida. 2014. It Happened Elsewhere: Remembering 1989 in the Former Yugoslavia. In Twenty Years after Communism: The Politics of Memory and Commemoration, eds. M. Bernhard and J. Kubik, 233-260. Oxford: Oxford University Press. 
ICG. 2000. Reunifying Mostar: Opportunities for Progress. International Crisis Group Balkan Report No. 90. Sarajevo: ICG.

- 2003. Building Bridges in Mostar. International Crisis Group Balkan Report No. 150. Sarajevo: ICG. http://www.crisisgroup.org/ /media/Files/ europe/150_building_bridges_mostar.ashx [20.05.2009].

- 2009. Bosnia's Dual Crisis: International Crisis Group Balkan Report.

Sarajevo: ICG. http://www.crisisgroup.org/ //media/Files/europe/B57\%20 Bosnias\%20Dual\%20Crisis.ashx [20.05.2009].

Ivanov, Andrey. 1996. The Balkans Divided: Nationalism, Minorities, and Security. Frankfurt/Main: Peter Lang.

Jäger, Friedrich. 2001. Bosniaken, Kroaten, Serben: Ein Leitfaden ihrer Geschichte.

Frankfurt/Main: Lang.

Jansen, Stef. 2005. Who's Afraid of White Socks? Towards a Critical Understanding of Post-Yugoslav Urban Self-Perceptions. Ethnologia Balkanica 9: $151-167$.

-2015. Yearnings in the Meantime: 'Normal Lives' and the State in a Sarajevo Apartment Complex. New York: Berghahn.

Kappel, Rolf, Marie-Laure Müller, Dino Dipa, and Selma Kapo. 2006. Durable Returns to a Durable State? An Opinion Poll on the Situation of Returnees in Bosnia and Herzegovina. Sarajevo: Swiss Development Cooperation (SDC). Koschnick, Hans, and Jens Schneider. 1995. Brücke über die Neretva: Der Wiederaufbau von Mostar. Munich: Deutscher Taschenbuch Verlag.

Lampe, John R. 1996. Yugoslavia as History: Twice There Was a Country. Cambridge: Cambridge University Press.

Lockwood, William G. 1975. European Moslems: Economy and Ethnicity in Western Bosnia. New York: Academic Press.

Lovrenović, Ivan. 1999. Bosnien und Herzegowina: Eine Kulturgeschichte. 2nd ed. Vienna; Bozen: Folio Verlag. Original edition, 1998.

Malcolm, Noel. 2002. Bosnia: A Short History. London: Pan. Original edition, 1994.

Meier, Viktor, and Sabrina P. Ramet. 1999. Yugoslavia: A History of Its Demise. London: Routledge.

Melčić, Dunja. 2007. Der Jugoslawien-Krieg: Handbuch zu Vorgeschichte, Verlauf und Konsequenzen. 2nd ed. Wiesbaden: VS Verlag für Sozialwiss.

Milošević, Milan. 2000. The Media Wars: 1987-1997. In Burn This House: The Making and Unmaking of Yugoslavia, eds. J. Udovicki and J. Ridgeway, 109130. Durham: Duke University Press.

Palmberger, Monika. 2006. Making and Breaking Boundaries: Memory Discourses and Memory Politics in Bosnia and Herzegovina. In The Western 
Balkans - A European Challenge. On the Decennial of the Dayton Peace Agreement, eds. M. Bufon, A. Gosar, S. Nurković, and A.-L. Sanguin, 525536. Koper: Založba Annales.

2008. Nostalgia Matters: Nostalgia for Yugoslavia as Potential Vision

for a Better Future? Sociologija. Časopis za sociologiju, Socijalnu Psihologiju $i$ Socijalnu Antropologiju 50(4): 355-370.

. 2013. Renaming of Public Space: A Policy of Exclusion in Bosnia and Herzegovina. Kakanien Revisited 1-11.

Pantic, Dragomir. 2002. Heterostereotypes of Serbs Towards Nations of the Former Yugoslavia and Other Nations. In Den Anderen im Blick: Stereotype im ehemaligen Jugoslawien, ed. A. Moritsch, 67-88. Frankfurt/Main: Lang.

Pavkovic, Alexandar. 1997. The Fragmentation of Yugoslavia: Nationalism in a Multinational State. London: Macmillan Press.

Pavlowitch, Stevan K. 1992. Tito: Yugoslavia's Great Dictator: A Reassessment. London: Hurst.

Perica, Vjekoslav. 2002. Balkan Idols: Religion and Nationalism in Yugoslav States. Oxford: Oxford University Press.

Price, Monroe. 2002. Memory, the Media and Nato: Information Intervention in Bosnia-Herzegovina. In Memory and Power in Post-War Europe: Studies in the Presence of the Past, ed. J.-W. Müller, 137-184. Cambridge: Cambridge University Press.

Radonic, Ljiljana. 2010. Krieg um die Erinnerung. Kroatische Vergangenheitspolitik zwischen Revisionismus und europäischen Standards. Frankfurt/Main: Campus.

Ramet, Sabrina P. 2002. Balkan Babel: The Disintegration of Yugoslavia from the Death of Tito to the Fall of Milosevic. Boulder: Westview.

Ramet, Sabrina P., and Ljubiša S. Adamovich. 1995. Beyond Yugoslavia: Politics, Economics, and Culture in a Shattered Community, Eastern Europe after Communism. Boulder: Westview.

Schmider, Klaus. 2002. Partisanenkrieg in Jugoslawien 1941-1944. Hamburg: Mittler.

Schöpflin, George. 1993. The Rise and Fall of Yugoslavia. In The Politics of Ethnic Conflict Regulation: Case Studies of Protracted Ethnic Conflicts, eds. J. McGarry and B. O’Leary, 172-203. London: Routledge.

Sekulic, Dusko, Garth Massey, and Randy Hodson. 1994. Who Were the Yugoslavs? Failed Sources of a Common Identity in the Former Yugoslavia. American Sociological Review 59(1): 83-97.

Sells, Michael A. 1996. The Bridge Betrayed: Religion and Genocide in Bosnia. Berkeley: University of California Press. 
Sorabji, Cornelia. 1995. A Very Modern War: Terror and Territory in BosniaHercegovina. In War: A Cruel Necessity? The Bases of Institutionalized Violence, eds. H. Watson and R.A. Hinde, 80-95. London: Tauris Academic Studies. 2008. Bosnian Neighbourhoods Revisited: Tolerance, Commitment and Komšiluk in Sarajevo. In On the Margins of Religion, eds. F. Pine and J.D. Pina-Cabral, 97-112. New York: Berghahn Books.

Stanovčić, Vojislav. 1988. History and Status of Ethnic Conflicts. In Yugoslavia, a Fractured Federalism, ed. D.I. Rusinow, 23-40. Washington, DC and Lanham, MD: Wilson Center Press.

Stefansson, Anders. 2010. Coffee after Cleansing? Co-Existence, Co-Operation, and Communication in Post-Conflict Bosnia and Herzegovina. Focaal Journal of Global and Historical Anthropology 57: 62-76.

Tepavac, Mirko. 2000. Tito: 1945-1980. In Burn This House: The Making and Unmaking of Yugoslavia, eds. J. Udovicki and J. Ridgeway, 34-79. Durham and London: Duke University Press.

Tomasevich, Jozo. 2001. War and Revolution in Yugoslavia, 1941-1945: Occupation and Collaboration. Stanford, CA: Stanford University Press. Tomić, Zoran, and Nevenko Herceg. 1999. Izbori u Bosni i Hercegovina. Mostar: Sveučiliste u Mostaru centar za studije novinarstva.

Velikonja, Mitja. 2003. Religious Separation and Political Intolerance in BosniaHerzegovina. Vol. 20. Eastern European Studies. Texas: Texas A\&M University Press.

Wilson, Duncan. 1979. Tito’s Yugoslavia. Cambridge: Cambridge University Press. Yarwood, John. 1999. Rebuilding Mostar: Urban Reconstruction in a War Zone, Town Planning Review Special Studies. Liverpool: Liverpool University Press. Žepić, Božo. 2006. Hercegovina između negiranja i opstanka. Status: Magazin za (Političku) kuluturu i društvena pitanja 8: 141-149.

Open Access This chapter is distributed under the terms of the Creative Commons Attribution 4.0 International License (http://creativecommons.org/licenses/by/4.0/), which permits use, duplication, adaptation, distribution, and reproduction in any medium or format, as long as you give appropriate credit to the original author(s) and the source, a link is provided to the Creative Commons license, and any changes made are indicated.

The images or other third party material in this chapter are included in the work's Creative Commons license, unless indicated otherwise in the credit line; if such material is not included in the work's Creative Commons license and the respective action is not permitted by statutory regulation, users will need to obtain permission from the license holder to duplicate, adapt or reproduce the material.

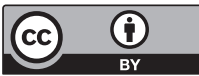

